\title{
Evolving Role of Vorinostat Combined with Radiation Therapy in the Treatment of Brain Tumors, from the Lab to the Clinic
}

\author{
Y. R. Lawrence \\ Thomas Jefferson University and Hospitals \\ P. Wachsberger \\ Thomas Jefferson University and Hospitals \\ Y. Liu \\ Thomas Jefferson University and Hospitals \\ B. Andersen \\ Thomas Jefferson University and Hospitals
}

A. P. Dicker

Thomas Jefferson University and Hospitals Follow this and additional works at: https://jdc.jefferson.edu/bodinejournal

Part of the Oncology Commons

Let us know how access to this document benefits you

\section{Recommended Citation}

Lawrence, Y. R.; Wachsberger, P.; Liu, Y.; Andersen, B.; and Dicker, A. P. (2010) "Evolving Role of Vorinostat Combined with Radiation Therapy in the Treatment of Brain Tumors, from the Lab to the Clinic," Bodine Journal: Vol. 3 : Iss. 1 , Article 36.

DOI: https://doi.org/10.29046/TBJ.003.1.035

Available at: https://jdc.jefferson.edu/bodinejournal/vol3/iss1/36

This Article is brought to you for free and open access by the Jefferson Digital Commons. The Jefferson Digital Commons is a service of Thomas Jefferson University's Center for Teaching and Learning (CTL). The Commons is a showcase for Jefferson books and journals, peer-reviewed scholarly publications, unique historical collections from the University archives, and teaching tools. The Jefferson Digital Commons allows researchers and interested readers anywhere in the world to learn about and keep up to date with Jefferson scholarship. This article has been accepted for inclusion in Bodine Journal by an authorized administrator of the Jefferson Digital Commons. For more information, please contact: JeffersonDigitalCommons@jefferson.edu. 


\section{Evolving Role of Vorinostat Combined with Radiation Therapy in the Treatment of Brain Tumors, from the Lab to the Clinic}

Lawrence, Y.R., Wachsberger, P., Liu, Y., Andersen, B., Dicker, A.P.

1Department of Radiation Oncology, Thomas Jefferson University Hospitals, Philadelphia, PA

\section{Purpose/Objective(s)}

Radiation therapy (RT) is a critical element in the treatment of both brain metastases and glioblastoma (GBM). Temozolomide (TMZ) has an established role in the upfront treatment of GBM. Down-regulated mismatch repair (MMR) is a known mechanism of resistance to TMZ. Vorinostat (SAHA), an HDAC inhibitor, has successfully been combined with a number of cytotoxic agents, including ionizing radiation (IR). We performed a series of preclinical and clinical studies to examine the role of SAHA in the treatment of brain tumors.

\section{Material/Methods, Preclinical}

Experiments were performed with 2 GBM cell lines. DNA double strand breaks were quantified by both neutral-comet assay and gamma-H2AX immunohistochemistry. For the neutral comet assay the 'olive moment' represents DNA damage. For gamma-H2AX assay, the percentage of cells with more than 3 foci was scored.

\section{Methods, Clinical}

A multicenter dose-escalation phase I trial, based on Fibonacci 3+3 design is being conducted. Whole-brain radiation is delivered in daily fractions of 2.5 Gy over 3 weeks (total dose 37.5 Gy). Vorinostat is delivered once daily on days of radiation therapy. Dose levels: increase from $200 \mathrm{mg}$ PO qd to $400 \mathrm{mg}$ PO qd in subsequent cohorts. Expected total accrual: 9-18 patients. Primary endpoint: tolerability.

\section{Results, Preclinical}

In the absence of drug, radiation-induced DNA-double strand breaks were almost completely repaired within 24-hours. Both TMZ + IR, and SAHA + IR increased the olive moment compared to IR alone (24 hour post IR time-point). Surprisingly, when TMZ and SAHA were combined together with IR, the olive moment decreased to 6.5 as compared to TMZ + IR alone $8.7(\mathrm{p}<0.05)$. Similarly, in the absence of IR, SAHA was found to decrease TMZ-induced DNA damage. Comparable results were obtained with gamma-H2AX assay and with the 2 nd cell line. On qPCR, SAHA decreased expression of key genes involved in
MMR. Despite this, clonogenic radiation survival assays demonstrated TMZ + SAHA to be more effective than TMZ alone in potentiating the cytotoxic effect of IR.

\section{Results, Clinical}

Initial results indicate that low dose Vorinostat combined with RT is well tolerated, dose escalation is continuing.

\section{Conclusion}

SAHA shows promise as a radiosensitzer for brain tumors. The discrepancy between DNA-damage and clonogenic-cell-survival assays suggests that SAHA's mechanism of radiosensitization may involve more than potentiation of DNA-damage. The efficacy of Vorinostat combined with temozolomide requires further investigation. Future clinical trials will investigate short-course doseescalated drug schedules. 